\title{
PEMANFAATAN LINGKUNGAN SEBAGAI MEDIA PEMBELAJARAN OLEH GURU PENJASORKES SEKOLAH MENENGAH PERTAMA DI DAERAH PESISIR KABUPATEN KEBUMEN
}

\author{
Umar Nurzaman $^{1}$, Sulaiman ${ }^{2}$, Agus Widodo Suripto ${ }^{3}$ \\ Universitas Negeri Semarang, Semarang
}

\begin{abstract}
Info Artikel
Sejarah Artikel:

Diterima Desember 2017

Disetujui Mei 2018

Dipublikasikan Agustus 2018

\section{Keywords:}

Lingkungan pesisir, media pembelajaran, tempat belajar

Abstrak media pembelajaran oleh guru penjasorkes SMP di daerah pesisir Kabupaten Kebumen. Metode penelitian ini menggunakan pendekatan penelitian kualitatif dengan teknik pengumpulan data menggunakan teknik wawancara, observasi, dan dokumentasi. Subjek penelitian ini terdiri dari 7 sekolah menengah pertama di daerah pesisir yang terdiri dari SMP Negeri 1 Mirit, SMP Negeri 1 Ambal, SMP Negeri 2 Ambal, SMP PGRI 1 Ambal, SMP Negeri 1 Petanahan dan SMP Negeri 1 Ayah serta SMP Negeri 2 Ayah. Instrumen penelitian menggunakan Pedoman wawancara dan foto dokumentasi. Hasil penelitian lingkungan yang dimanfaatkan sebagai tempat pembelajaran di daerah pesisir Kabupaten Kebumen meliputi, lapangan desa, pantai, dan jalan disekitar sekolah. Lingkungan yang dimanfaatkan sebagai media pembelajaran penjasorkes terdiri dari kartu tugas dan bola berekor yang terbuat dari kertas tugas, modifikasi bola kasti dari sabut kelapa, bejana berlubang yang terbuat dari ember bekas, tutup ember cat dan papan kayu untuk penunjang pembelajaran. Simpulan dari penelitian ini adalah guru penjasorkes daerah pesisir kabupaten kebumen menggunakan berbagai cara untuk memanfaatkan lingkungan sebagai tempat belajaran dan media pembelajaran seperti lapangan desa untuk pembelajaran permainan bola besar dan permainan bola kecil, sedangkan pantai dan akses jalan sekolah dimanfaatkan untuk pembelajaran atletik.

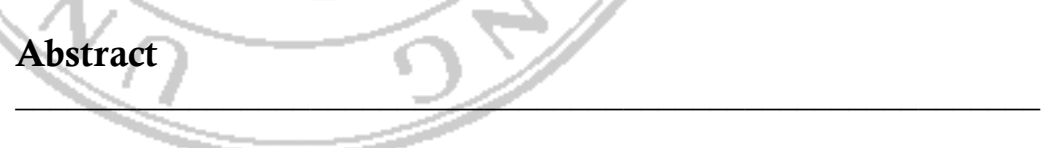

$\bar{T}$ The purpose of this research is to know the types and ways to utilize the environment as a medium of learning by junior high school teachers in the coastal area of Kebumen Regency. This research method using qualitative research approach with data technique using interview technique, observation, and documentation. The subjects of this study consist of 7 junior secondary schools in coastal areas consisting of SMP Negeri 1 Mirit, SMP Negeri 1 Ambal, SMP Negeri 2 Ambal, SMP PGRI 1 Ambal, SMP Negeri 1 Petanahan and SMP Negeri 1 Ayah and SMP Negeri 2 Ayah. The research instrument uses interview guides and photo documentation. The results of environmental research are used as a place of learning in the coastal area Kebumen District, village buildings, beaches, and roads around the school. The environment used as learning media for penjasorkes consists of paper assignment, modification of ball from coconut husk, perforated vessel made from used bucket, paint bucket cover and wood board for supporting learning. The conclusion of this research is the teacher of the coastal area surveyor Kebumen uses various ways to utilize the environment as a place of learning and learning media such as field to learn big ball game and small ball game, while beach and school access road for learning athletics
\end{abstract}

(C) 2018 Universitas Negeri Malang 


\section{PENDAHULUAN}

Pendidikan jasmani olahraga dan kesehatan merupakan pendidikan media utamanya menggunakan aktivitas fisik atau jasmani. Setiawan Aji (2012:172) Pendidikan jasmani adalah pergaulan pedagogik dalam dunia gerak dan penghayatan jasmani. Menurut Ega Trisna Rahayu dalam bukunya strategi pembelajaran pendidikan jasmani, pendidikan jasmani adalah proses pendidikan yang memanfaatkan aktivitas jasmani yang direncankan secara sistematik bertujuan untuk mengembangkan dan meningkatkan individu secara organik, neoromuskular, perseptual, kognitif, dan emosional, dalam kerangka pendidikan nasional (Trisna Ega: 2013, 7). Aktivitas jasmani yang dipilih disesuaikan dengan tujuan yang ingin dicapai dan kapabilitas siswa. Aktivitas fisikal yang dipilih ditekankan pada berbagai aktivitas jasmani yang wajar, aktivitas jasmani yang membutuhkan sedikit usaha sebagai aktivitas rekreasi dan atau aktivitas jasmani yang sangat membutuhkan upaya keras seperti untuk kegiatan olahraga kepelatihan atau prestasi.

Pendidikan jasmani olahraga dan kesehatan mempunyai tujuan yang sama dengan tujuan pendidikan nasional yaitu membekali siswa dengan ketrampilan atau life skill yang berguna sebagai bekal dalam menjalani kehidupan di kemudian hari. Menurut Aris Shoimin, "Sistem pendidikan di Indonesia harus di fokuskan pada keberhasilan peserta didik dengan jaminan kemampuan yang diarahkan pada life skill yang dikemudian hari dapat menopang kesejahteraan peserta didik itu sendiri untuk keluarganya serta masa depannya dengan kehidupan yang layak di masyarakat"(Shoimin Aris, 2014:15). Salah satu ketercapaian tujuan pembelajaran PJOK adalah membekali siswa terampil, tanggap dan mampu menyelesaikan permasalahan yang dihadapi di lingkungan tempat tinggalnya.

Lingkungan merupakan tempat berlangsungnya aktivitas kehidupan masyarakat setiap hari. Setiap daerah memiliki karakteristik lingkungan yang berbeda-beda. Sehingga pola hidup masyarakat di setiap daerah akan berbeda pula. Dengan adanya pembelajaran PJOK yang memanfaat lingkungan sebagai media pembelajaran atau sebagai tempat belajar maka akan dapat membekali ketrampilan siswa dalam kehidupan sehari-harinya di lingkungan tempat tinggalnya. Masa yang sesuai untuk membekali ketrampilan sisiwa adalah pada jenjang Sekolah
Menengah Pertama. Pengalaman belajar pada mata pelajaran Pendidikan Jasmani Olahraga dan Kesehatan diarahkan untuk membina pertumbuhan fisik dan pengembangan psikis secara lebih baik, sekaligus membentuk pola hidup sehat dan bugar sepanjang hayat. Guru penjasorkes yang profesional sangat penting perannya guna tercapainya pembelajaran penjasorkes. Seperti yang diungkapkan oleh Herka maya. K (2005:89) Menjelaskan bahwa seorang guru yang profesional adalah guru yang memiliki kompetensi tinggi dalam mengajar. Mereka dapat merancang atau mendesain suatu kegiatan pembelajaran pada kondisi apapun. Baik itu sarana prasarana yang minim, lingkungan yang kurang kondusif, bahkan peserta didik yang memiliki latar belakang kemampuan afektif, kognitif, psikomotor, dan fisik yang berbeda. Dalam penggunaan media pembelajaran guru dituntut untuk selalu kreatif memanfaatkannya atau menciptakan media tersebut. (Adang Suherman, 2000) Pembelajaran penjasorkes dengan pemanfaatan lingkungan disetiap wilayah berbeda-beda. Hal ini disesuaikan dengan kondisi geografis lingkungan dimana pembelajaran berlangsung.

Kabupaten Kebumen memiliki 221 sekolah menengah pertama yang tersebar di setiap kecamatan, 24 sekolah diantaranya berada didaerah pesisir. Sekolah tersebut berada di delapan kecamatan daerah pesisir, meliputi kecamatan Ayah, Buayan, Puring, Petanahan, Klirong, Buluspesantren, Ambal, dan Mirit.

Peneliti telah melakukan observasi awal di beberapa SMP yaitu SMP 1 Ayah, SMP 2 Ayah, SMP Negeri 1 Petanahan, SMP Negeri 1 Ambal dan SMP PGRI 1 Ambal untuk mengetahui kondisi lingkungan sekitar sekolah. Hasil observasi tersebut disajikan dalam Tabel 1.1 berikut.

Tabel 1. Hasil Observasi Lingkungan Sekitar Sekolah

\begin{tabular}{|c|c|c|}
\hline No & Nama Sekolah & $\begin{array}{c}\text { Lingkungan Sekitar } \\
\text { Sekolah }\end{array}$ \\
\hline 1 & SMP Negeri 1 Ayah & $\begin{array}{l}\text { - Akses Jalan Desa } \\
\text { - Persawahan } \\
\text { - Lapangan Desa } \\
\text { - Pantai }\end{array}$ \\
\hline 2 & SMP Negeri 2 Ayah & $\begin{array}{l}\text { - Akses Jalan Desa } \\
\text { - Perbukitan Kars } \\
\text { - Pantai } \\
\text { - Lapangan Desa }\end{array}$ \\
\hline 3 & SMP PGRI 1 Ambal & $\begin{array}{l}\text { - Lapangan Desa } \\
\text { - Persawahan } \\
\text { - Jalan Desa }\end{array}$ \\
\hline 4 & SMP Negeri $1 \mathrm{Ambal}$ & $\begin{array}{l}\text { - } \text { Pantai Ambal } \\
\text { - Tempat Kerajinan } \\
\text { Sabut Kelapa } \\
\end{array}$ \\
\hline
\end{tabular}




\begin{tabular}{|c|c|c|}
\hline No & Nama Sekolah & $\begin{array}{c}\text { Lingkungan Sekitar } \\
\text { Sekolah }\end{array}$ \\
\hline & & - Lapangan Desa \\
\hline 5 & SMP Negeri 1 Petanahan & $\begin{array}{l}\text { - Pantai Petanahan } \\
\text { - Lapangan Desa } \\
\text { - Gor Kecamatan } \\
\text { - Agro wisata }\end{array}$ \\
\hline
\end{tabular}

Hasil temuan observasi awal Sekolah Menengah Pertama di daerah pesisir tidak mempunyai tempat yang luas untuk melakukan pembelajaran penjasorkes. Sedangkan disekitar sekolah terdapat lingkungan berupa bibir pantai yang panjang, industri kerajinan sabut kelapa, dan argo wisata perkebunan. Lapangan desa, dan akses jalan menuju sekolah yang bisa di manfaatkan sebagai media atau sebagai tempat pembelajaran.

Berdasarkan kondisi tersebut, peneliti tertarik untuk melakukan penelitian terhadap pemanfaatan lingkungan sebagai media pembelajaran atau tempat belajar penjasorkes sekolah menengah pertama di daerah pesisir Kabupaten Kebumen. Peneliti ingin mengetahui lebih dalam tentang pemanfaatan lingkungan di daerah pesisir sebagai media pembelajaran atau sebagai tempat belajar.

Sehubungan dengan latar belakang masalah yang telah diungkapkan dapat dirumuskan beberapa rumuasan masalah, yang pertama adalah lingkungan apa saja yang dimanfaatkan sebagai media pembelajaran atau tempat belajar oleh guru Pendidikan Jasmani Olahraga dan Kesehatan di Sekolah Menengah Pertama daerah Pesisir Kabupaten Kebumen?, dan yang kedua adalah bagaimana guru memanfaatkan lingkungan sebagai media pembelajaran PJOK di Sekolah Menengah Pertama Negeri daerah pesisir Kabupaten Kebumen.

Tujuan dari penelitian ini adalah untuk mengetahui jenis lingkungan yang dimanfaatkan sebagai media pembelajaran atau tempat belajar oleh guru penjasorkes di daerah pesisir Kabupaten Kebumen, dan untuk mengetahui bagaimana guru memanfaatkan lingkungan sebagai media pembelajaran PJOK di Sekolah Menengah Pertama Negeri daerah pesisir Kabupaten Kebumen.

\section{METODE}

Desain penelitian merupakan cetak biru yang menentukan pelaksanaan selanjutnya. Desain penelitian memaparkan apa, mengapa, dan bagaimana, masalah tersebut diteliti dengan menggunakan prinsip-prinsip metodologis .(W. Gulo, 2000 : 99) Penelitian ini adalah penelitian yang bersifat kualitatif, karena bermaksud untuk meneliti dan memasukkan informasi sebanyakbanyaknya dari suatu kejadian tertentu. Penelitian ini bermaksud untuk mengetahui dan menemukan informasi sebanyak banyaknya dari suatu kejadian tertentu dan berusaha memberi gambaran tentang seberapa besar tingkat kreativitas guru penjasorkes dalam memanfaatkan lingkungan sebagai media pembelajaran penjasorkes di Sekolah Menengah Pertama khususnya di daerah pesisir Kabupaten Kebumen. Penelitian ini menggunakan kualitatif dengan pengambilan data menggunakan teknik wawancara dan observasi.

Subjek penelitan adalah data yang akan kita teliti, apabila dalam penelitan kualitatif dikenal dengan populasi dan sampel. Subjek penelitian biasanya dipakai dalam penelitan kualitatif, dan jumlahnya tidak banyak (Mia Kusumawati, 2015:100). Teknik pengambilan subjek penelitian adalah dengan purposif sampling, yaitu memilih atau menyeleksi atas dasar kriteria terntentu yang dibuat periset berdasarkan tujuan penilitian (Rahmat Kriyanto, 2010:158). Pada penelitian ini subjek penelitian adalah guru penjasorkes yang ada didaerah pesisir Kabupaten Kebumen. Pemilihan subjek penetian ini dipilih berdasarkan tempat sekolahnya. Mulai dari sekolah yang dekat dengan pantai, sampai sekolah yang jauh dari pantai tetapi masih dalam wilayah pesisir Kabupaten Kebumen. Berikut adalah daftar sekolah yang akan dijadikan subjek penelitian yaitu SMP Negeri 1 Mirit, SMP Negeri 1 Ambal, SMP Negeri 2 Ambal, SMP PGRI 1 Ambal, SMP Negeri 1 Petanahan, SMP Negeri 1 Ayah dan SMP Negeri 2 Ayah.

Analisis data kualitatif dimulai dari analisis berbagai data yang telah dikumpulkan peneliti baik wawancara, observasi, dan dokumentasi. Kemudian data tersebut diklasifikasikan kedalam katagori-katagori tertentu. Pengklasifikasian atau pengkatagorian ini mempertimbangkan kesahihan (kevalidan), dengan memperhatikan kompetensi subjek penelitian, tingkat auntentisitasnya dan melakukan triangulasi sebagai sumber data (Kriyantono, 2006:197).setelah diklasifikasikan, peneliti melakukan pemakaian data tersebut, peneliti dituntut berteori agar dapat menjelaskan dan mempertahankan argumentasinya (blocking interpretation).

Proses analisis data dimulai peneliti dengan mengumpulkan seluruh informasi seluruh data yang diperoleh dari wawancara, observasi dan dokumentasi. Pada analisis data mengenai kompetensi guru penjasorkes 
mengenai pemanfaatan lingkungan daerah pesisir sebagai media pembelajaran. Peneliti mengelompokan data-data tersebut kedalam katagori kompetensi guru yaitu, kompetensi kepribadian, kompetensi pedagogik, kompetensi profesional, dan kompetensi sosial. Peneliti melakukan triangulasi metode, yaitu mengklarifikasi data yang didapat dengan wawancara, dan dokumentasi dengan metode observasi. Observasi untuk menguji keabsahan data tersebut dilakukan dengan cara mengamati aktivitas pembelajaran guru.
Penelitian ini menggunakan tipe deskriptif-kualitatif. Tipe penelitian ini didasarkanpada pertanyaan dasar 'bagaimana' (Gulo, 2000:19). Jika penelitian eksploratif melakukan penjajakan terhadap gejala atau suatu peristiwa, penelitian deskriptif berusaha menggali

\section{HASIL}

Tabel 2. Hasil Pengambilan Data Berdasarkan Standar Kompetensi Kurikulum pembelajaran

\begin{tabular}{|c|l|l|}
\hline No & \multicolumn{1}{|c|}{ Standar Kompetensi } & \multicolumn{1}{c|}{ Hasil Penelitian } \\
\hline 1 & $\begin{array}{l}\text { Memahami dan mempraktikan konsep keterampilan } \\
\text { gerak fundamental permainan bola besar }\end{array}$ & $\begin{array}{l}\text { Tujuh sekolah memilh materi permainan bola besar } \\
\text { yaitu permainan sepakbola dengan memanfaatkan } \\
\text { lapangan desa yang ada di sekitar sekolah }\end{array}$ \\
\hline 2 & $\begin{array}{l}\text { Memahami dan mempraktikkan konsep keterampilan } \\
\text { gerak fundamental permainan bola kecil }\end{array}$ & $\begin{array}{l}\text { SMP Negeri 2 Ambal memilih materi bola kasti dan } \\
\text { softball dengan memodifikasi bola kastiny. SMP Negeri } \\
\text { 1-Petanahan memilih materi bulutangkis dengan } \\
\text { memanfaatkan Gor Kecamatan sebagai tempat belajar. }\end{array}$ \\
\hline 3 & $\begin{array}{l}\text { Memahami dan mempraktikan gerak spesifik jalan, lari, } \\
\text { lompat dan lempar dalam berbagai permainan } \\
\text { sederhana dan atau tradisional }\end{array}$ & $\begin{array}{l}\text { Materi lari dengan memanfaatkan jalan di sekitar } \\
\text { sekolah yaitu SMP Negeri 1 Ayah, SMP Negeri 1 Mirit, } \\
\text { SMP PGRI 1 Ambal, Kemudian SMP Negeri 2 Ambal } \\
\text { dan SMP Negeri 1 Petanahan menggunakan bibir } \\
\text { pantai untuk materi atletik nomor lari sprint }\end{array}$ \\
\hline 4 & $\begin{array}{l}\text { Memahami dan mempraktikkan konsep latihan } \\
\text { peningkatan derajat kebugaranjasmani yang terkait } \\
\text { dengan kesehatan (daya tahan, kekuatan, komposisi } \\
\text { tubuh, dan kelenturan) dan pengukuran hasilnya. }\end{array}$ & $\begin{array}{l}\text { SMP Negeri 2 Ambal menggunakan teknik pengukuran } \\
\text { MFT (Multilevel Fitnes Test) dengan memanfaatkan } \\
\text { media audio pengeras suara dan memanfaatkan papan } \\
\text { kayu yang dijadikan sebagai pembatas antar siswa }\end{array}$ \\
\hline
\end{tabular}

Memahami dan Mempraktikan Konsep Ketrampilan Gerak Fundramental Permainan Bola Kecil

Pada standar kompetensi materi ini guru penjasorkes yang memanfaatkan lingkungan sebagai tempat belajar adalah guru penjasorkes SMP Negeri 1 Petanahan dengan memanfaatkan Gor Kecamatan untuk pembelajaran materi bulutangkis. Hal lain dari guru penjasorkes SMP Negeri 2 Ambal memanfaatkan lingkungan yang ada yaitu sabut kelapa yang digunakan untuk mengisi bola plastik kecil yang di jadikan bola kasti atau bola softball. Selain itu, memanfaatkan kertas bekas yang didaur ulang untuk dijadikan kertas tugas. Kertas tugas tersebut berisi tentang petunjuk dan arahan untuk melakukan sebuah gerakan.

Memahami dan mempraktikan gerak spesifik jalan, lari, lompat, dan lempar dalam berbagai permainan sederhana dan atau tradisional

Standar kompetensi ini materi yang dipilih dengan memanfaatkan lingkungan sekitar adalah memanfaatkan bibir pantai yang digunakan lintasan lari. Guru penjasorkes yang memanfaatkan bibir pantai sebagai lintasan lari adalah SMP Negeri 1 Ambal dan SMP Negeri 1 Petanahan. Perjalanan menuju pantai siswa dan guru bersepada dengan jarak 2 kilometer. Selain memanfaatkan bibir/pantai sebagai tempat belajar, guru penjasorkes lainnya yaitu SMP Negeri 1 Mirit, SMP PGRI 1 Ambal, SMP Negeri 1 Ayah dan SMP Negeri 2 Ayah memanfaatkan akses jalan sekitar lingkungan sekolah untuk dijadikan lintasan lari

\section{Cara Memanfaatkan Lingkungan sebagai Media Pembelajaran Oleh Guru Penjasorkes}

Cara guru penjasorkes di daerah pesisir dalam memanfaatkan lingkungan sebagai media pembelajaran adalah sebagai berikut :

\section{SMP Negeri 1 Ambal}

Memanfaatkan lapangan desa dengan cara siswa diajak menuju lapangan, kemudian setelah sampai di lapangan siswa dikumpulkan dan guru memberikan penjelasan tentang materi yang akan disampaikan.

Pantai Ambal dengan cara guru masuk ke kelas terlebih dahulu untuk memberikan arahan menuju ke pantai ambal, kemudian siswa dan guru bersama-sama menuju pantai menggunakan sepeda. Setelah sampai di pantai 
siswa melakukan pemanasan dan guru dibantu salah satu siswa untuk membuat lintasan lari menggunakan cone. Selanjutnya guru memberikan penjelasan dan pemanasan khusus tentang materi lari sprint $400 \mathrm{~m}$. Setelah itu,siswa mempraktikan lari dan diambil hasnya.

\section{SMP Negeri 2 Ambal}

Limbah sabapa digunakan untuk mengisi bolaplastik kecil yang digunakan untuk materi permainan bola kecil yaitu softball dan kasti.

Bekas kertas undangan pernikahan dan bekas kertas folio dimanfaatkan untuk kertas tugas yang didalamnya berisi petunjuk dan perintah untuk memecahkan suatu gerakan.Tutup ember cat yang sudah dilubangi dijadikan cone dan wadah bola kasti dalam pembelajaran.

Laptop dan speaker digunakan untuk mengetes kebugaran siswa dengan menggunakan pengukuran MFT.

\section{SMP Negeri 1 Mirit}

Halaman sekolah dimanfaatkan untuk lari 400 meter. Panjang keliling halaman tersebut sepanjang 80 meter. Jadi siswa mengelilingi halaman sekolah sebanyak lima kali putaran.

Lapangan desa dimanfaatkannya untuk permainan bola besar yaitu sepakbola. Letak lapangan bersebelahan dengan sekolah, jadi guru langsung mengajak siswa untuk langsung menuju kelapangan dan langsung menjelaskan materinya.

\section{SMP PGRI 1 Ambal}

Lapangan desa dimanfaatkan untuk permainan bola besar dan permainan bola kecil. Guru mengajak siswa berjalan menuju lapangan dengan jarak dari sekolah kurang lebih $1 \mathrm{~km}$.

Setelah sampai di lapangan guru memerintahkan siswa putra untuk membuat tim dan bermainan. Sedangkan siswa putri melakukanm permainan bola voli bersama guru.

\section{SMP Negeri 1 Petanahan}

Penggunaan GOR Kecamatan Petanahan untuk pembelajaran penjasorkes terlebih dahulu ijin kepada pengelola gor kecamatan. Pembelajaran yang dilakukan di gor adalah permainan bola besar yaitu futsal dan permaianan bola kecil yaitu bulu tangkis. Pembelajaran futsal materi yang disampaikan adalah tentang teknik dasar passing dan kontrol. Sedangkan bulutangkis materinya adalah shadow dan permainan bulutangkis.
Pantai Petanahan dimanfaatkan untuk materi atletik yaitu lari sprint, lempar cakram dan lempar lembing. Jarak antara pantai dan sekolah kurang lebih $2 \mathrm{~km}$, sehingga untuk menuju kesana siswa dan guru menggunakan sepeda.

\section{SMP Negeri 1 Ayah}

Jalan desa dimanfaat dengan cara guru menjelaskan tentang materi lari jarak menengah atau jarak jauh. Setelah guru menjelaskan rute dan materi lari siswa mempraktikannya dengan diawali pemanasan terlebih dahulu. Panjang rute untuk mengelilingi desa sekitar sekolahan berjarak kurang lebih 300 meter.

Kertas bola berekor cara memanfaatkanya adalah dengan masing-masing siswa mendapat tugas untuk membawa dan mengumpulkan kertas bekas dan dijadikan bola.

\section{SMP Negeri 2 Ayah}

Jalan desa dimanfaatkan untuk lari mengelilingi permukiman warga yang ada di sekitar sekolah. Pembelajaran pertama dilakukan dengan siswa melakukan pemanasan didalam sekolahan. Setelah itu siswa melakukan lari sesuai dengan nomor urut absennya.

Kolam renang BSC gombong dimanfaatkan untuk materi aquatik. Pembelajaran renang dilaksanakan dua kali dalam satu semester. Jarak dari sekolah menuju kolam renang kurang lebih $5 \mathrm{~km}$. Sehingga untuk menuju ke kolam renang menggunakan mobil akungkutan desa. Tiket masuk kolam renang dan sewa angkutan ditanggung masingmasing siswa. Untuk meringankan hal tersebut guru membuat kebijakan agar setiap satu minggu siswa iuran Rp.1000,00 .

\section{PEMBAHASAN}

Menurut Tejo Nurseto dalam jurnal penelitiannya menjelaskan jenis-jenis media pembelajaran Menurut bentuk informasi yang digunakan, dapat memisahkan dan mengklasifikasi media dalam lima kelompok besar, yaitu media visual diam, media visual gerak, media audio, media audio visual diam, dan media audio visual gerak. Proses yang dipakai untuk menyajikan pesan, apakah melalui penglihatan langsung, proyeksi optik, proyeksi elektronik atau telekomunikasi. Dengan menganalisis media melalui bentuk penyajian dan cara penyajiannya, kita mendapatkan suatu format klasifikasi yang meliputi tujuh kelompok media penyaji, yaitu: 1. Grafis, bahan cetak, dan gambar diam 2 . 
Media proyeksi diam 3. Media audio, 4. Media audio visual diam, 5. Media Audio visual hidup/film, 6. Media televisi, dan 7. Multi media (Tejo Nuurseto, 2011:23).

Media pembelajaran merupakan segala bentuk perangsang dan alat yang disediakan guru untuk mendorong siswa belajar secara cepat, tepat, mudah, benar dan tidak terjadi verbalisme. Pengalaman belajar dapat diperoleh melalui:

a. situasi dan kondisi sesungguhnya.

b. mengamati benda pengganti dalam wujud alat peraga.

c. Membaca bahan-bahan cetakan seperti majalah, buku surat kabar, dan sebagainya.

Rowntree (1974:104-113) dalam

bukunya Dini Rosdiani (2013:72-73) mengelompokan media pembelajaran sebagai berikut :

a. Media Interaksi Insani

b. Media Realita

c. Pictorial

d. Simbol Tertulis

e. Rekaman Suara

Berdasarkan

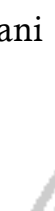

hasil

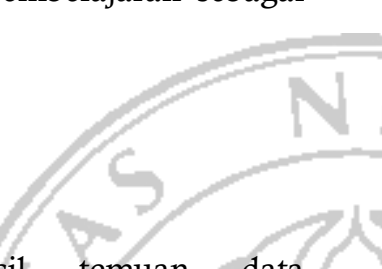

temuan data dilapangan diperoleh data tentang media yang digunakan oleh guru penjasorkes di daerah pesisir kabupaten Kebumen sesuai dengan dengan teori yang dikemukakan oleh Rowntree sebagai berikut

\section{Media interaksi insani}

Jenis media ini digunakan oleh semua informan dalam penelitian ini. Hal ini terlihat pada saat informan $2,3,4,5,6$, dan 7 menyampaikan secara verbal materi pengantar altetik pada nomor lari. Informan tersebut menjelaskan teknik-teknik lari mulai dari start hingga gerakan lari, serta menjelaskan rute jalan di sekitar sekolah atau pantai sebagai lintasan lari. Sementara itu informan 1 selain menyampaikan pengantar materi Multi Fitnes Tes pada materi tes kebugaran jasmani, informan juga menyisipkan materi biologi tentang respirasi tumbuhan yang ada di sekitar.

\section{Media Realita}

Informan 1 dan 6 menggunakan media realita dengan cara membuat beberapa kelompok. Masing-masing kelompok mempresentasikan permainan yang telah didiskusikannya, sementara kelompok lain mengamatinya. Sedangkan informan 7 menggunakan media realita ini dengan memberi contoh langsung kepada para siswa gerakan passing pada permainan sepakbola.

Selain menggunakan media realita berupa manusia (siswa ataupun informan), dalam pengamatan peneliti media realita lainnya yang digunakan berupa lintasan untuk lari dan lapangan untuk bermain sepakbola. Lintasan lari berupa pantai dimanfaatkan oleh informan 3 dan 7. Informan 3 menggunakan Pantai Ambal, sementara informan 7 menggunakan Pantai Petanahan. Kedua informan ini menggunakan pantai sebagai lintasan lari karena jaraknya yang dekat dan juga permukaan pantai yang datar dan cocok digunakan sebagai lintasan lari. Sementara itu informan 2, 4, 5, dan 6 menggunakan jalan di sekitar sekolah sebagai lintasan lari. Hal ini karena kontur pantai yang berbatuan sehingga tidak cocok digunakan sebagai lintasan lari. Ada pula sekolah yang cukup jauh dari pantai.

\section{Media Pictorial}

Media pictorial oleh informan 1 dengan cara memberikan tugas kepada siswa menggunakan kartu tugas kelompokKartu tersebut berisikan petunjuk atau instruksi untuk membuat sebuah gerakan ataupun sebuah permainan yang dikerjakan secara kelompok. Pada kartu yang berwarna merah, masingmasing nomor memiliki petunjuk yang berbeda-beda dan akan digilir untuk semua kelompok (dalam bentuk sirkuit training). Sementara kartu berwarna hijau terdapat lebih dari satu petunjuk yang ada pada setiap kartu.

\section{Media Tertulis}

Media terlulis digunakan oleh semua informan yaitu dalam bentuk modul yang diberikan kepada masing-masing siswa.

\section{Media Rekaman Suara}

Media rekaman suara digunakan oleh informan 1 yaitu dengan memberikan materi kebugaran jasmani dengan alat Multi Fitnes Test.

Berdasarkan pendapat ahli dan hasil temuan dilapangan dapat di simpulkan bahwa jenis- jenis media pembelajaran yang terdiri dari media interaksi Insani, media realita, media pictorial, dan media tertulis, serta media rekaman suara digunakan oleh guru penjasorkes SMP di daerah pesisir sebagai media pembelajaran.

\section{Peran,Fungsi dan Manfaat Media Pembelajaran Penjasorkes}

Peran dan fungsi alat dan media pembelajaran pendidikan jasmani adalah: 1) meningkatkan kualitas sumber daya manusia yang mampu bersaing dan kerjasama di era globalisasi. 2) meningkatkan ketrampilan dan kualitas fisik untuk mendukung aktivitas 
sehari-hari. 3) meningkatkan kemandirian dalam mengikuti intrakulikuler maupun ekstrakulikuler dan belajar di rumah (Rosdiani. D, 2013:47). Media pengajaran dapat mempertinggi proses belajar siswa dalam pengajaran yang pada gilirannya diharapkan dapat mempertinggi hasil belajar yang dicapai. Manfaat media pembelajaran dalam proses belajar siswa antara lain: a) pengajaran akan lebih menarik perhatian siswa sehingga dapat menumbuhkan motivasi belajar. b) bahan pengajaran akan lebih jelas maknanya sehingga dapat lebih dipahami oleh para siswa, dan memungkinkan siswa menguasai tujuan pembelajaran lebih baik.c) metode pembelajaran akan lebih bervariasi, tidak semata-mata komunikasi verbal melalui penuturan kata-kata oleh guru, sehingga siswa tidak bosan dan guru tidak kehabisan tenaga, apabila guru mengajar untuk setiap jam pelajaran. d) siswa akan lebih banyak melakukan kegiatan belajar, sebab tidak hanya mendengarkan uraian guru tetapi juga melakukan aktivitas lain sperti mengamati, melakukan, mendemonstrasikan dan lain-lain (Nana. S dan Ahmad Rifai, 2015:2).

Hasil pengambilan data dilapangan tentang peran dan fungsi alat dan media pembelajaran pendidikan jasmani adalah sebagai berikut. Menurut informan 1 peran dan fungsi media pembelajaran fungsi media pembelajaran sangat membantu sekali untuk menunjang proses pembelajaran. dengan media pembelajaran siswa akan memahami maksud dari materi pembelajaran yang disampaikan. (hasil wawancara tanggal $31 \mathrm{Juli}$ 2017). Kemudian menurut forman 2 fungsi dan peran media adalah agar siswa lebih/tertarik untuk mengikuti pembelajarannya(hasil wawancara tanggal 2 Agustus 2017). Menurut informan 3 peran dan fungsung media pembelajaran adalah sangat penting dalam menunjang proses pembelajaran. karena dengan adanya media pembelajaran materi yang disampaikan akan mengena disiswa. Seperti pemutaran video atau gambar olahraga (hasil wawancara tanggal 1 Agustus 2017). Sedangkan menurut informan 4 fungsi dan peran media pembelajaran adalah untuk menentukan pembelajaran berikutnya dan sebagai bahan evaluasi (hasil wawancara tanggal 4 Agustus 2017). Menurut informan 5 sama pendapatnya dengan informan 1 dan informan 3 yaitu fungsi media pembelajaran adalah untuk pembantu keberhasilan pembelajaran (hasil wawancara tanggal 5 agustus 2017). Menurut informan 6 fungsi media pembelajaran yaitu bisa berbagi ilmu, pengalaman, cara-cara membelajari anak, dan bisa bertukar fikiran (hasil wawancara tanggal 7 Agustus 2017). Menurut informan 7 fungsi dan peran media pembelajaran pendidikan jasmani adalah kembali ketujuan pembelajaran yaitu membuat anak senang, gembiran dan sehat (hasil wawancara10 Agustus 2017).

Dari hasil wawancara dilapangan dapat diambil kesimpulan bahawa fungsi dan peran media pembelajaran adalah untuk membantu siswa dalam memahami maksud materi yang disampaikan oleh guru sehingga media dapat membantu keberhasilan pembelajaran. selain itu peran dan fungsi media pembelajaran adalah untuk bahan evaluasi pembelajaran dan penentuan materi pelajaran berikutnya serta media pembelajaran akan membuat siswa senang, gembira dan sehat.

Pemanfaatan Lingkungan sebagai Media Pembelajaran atau sebagai Tempat Belajar Konsep modifikasi fasilitas pembelajaran maupun media pembelajaran memaparkan kondisi dan lingkungan sekolah yang dapat dimanfaatkan sebagai sarana, prasaran dan media pengajaran pendidikan jasmani olahraga dan kesehatan. Disamping itu juga dipaparkan cara membuat atau pengadaan sarana sederhana yang dapat dikembangkan/dibuat dari bahan-bahan yang ada disekitar lingkungan siswa (Rosdiani. D, 2013:49).

Pendapat lain menurut Rida. A dalam jurnalnya yang berjudul "Pengaruh Model Pembelajaran Pendidikan Lingkungan Berbasis Outdor Terhadap Penguasaan Konsep Pendidikan Lingkungan Bagi Calon Guru Sekolah Dasar" menjelaskan Salah satu model pembelajaran yang diharapkan dapat meningkatkan penguasaan konsep pendidikan lingkungan bagi calon guru adalah pembelajaran di luar kelas (outdoor). Pembelajaran pendidikan lingkungan di luar kelas dilaksanakan dengan melibatkan siswa untuk menyatu dengan alam dan melakukan berbagai aktivitas pembelajaran yang mengarah pada terwujudnya perilaku siswa peduli terhadap lingkungan melalui tahap pemahaman, penyadaran, perhatian, tanggung jawab, dan tingkah laku (KLH, 2005). Model pembelajaran pendidikan lingkungan berbasis outdoor memiliki karekteristik sebagai berikut: a) Kegiatan pembelajaran mengkaji permasalahan lingkungan sekolah. b) Pembelajaran menggunakan fasilitas belajar yang ada diluar kelas dan di dalam kelas. c) Menekankan pada aspek sikap peduli terhadap lingkungan sekolah disamping aspek kognitif 
dan kinerja (Risda Amini dan Munandar. A, 2010:16).

Hal ini sesuai dengan temuan peneliti di lapangan tentang pembelajaran yang memanfaatkan lingkungan sebagi tempat belajar dan sebagai media pembelajaran. Seperti pembelajaran yang disampaikan oleh informan 3 guru Penjasorkes SMP Negeri 1 Ambal yang memanfaatkan Pantai Ambal Sebagai tempat lintasan lari jarak $400 \mathrm{~m}$. Selain memanfaatkan pantai sebagai tempat pembelajaran guru mengajak siswa untuk peduli terhadap lingkungan pantai dengan cara memungut/mengambil sampah yang ada di sekitar lingkungan pantai. Hal serupa juga digunakan oleh Guru Penjasorkes SMP Negeri 1 Petanahan yaitu informan 7 dalam wawancaranya menjelaskan bahwa dalam pembelajaran yang memanfaatkan lingkungan sebagai tempat belajar beliau memanfaatkan Gedung Olahraga Kecamatan dan Pantai Petanahan. GOR kecamatan dimanfaatkan untuk pembelajaran permainan bola besar dan permainan bola kecil yaitu futsal dan bulutangkis. Sedangkan di pantai petanahan dimanfaatkan untuk pembelajaran atletik yaitu lari sprint, lompat jauh, dan lempar cakram ( hasil wawancara tanggal 4 Agustus 2017) sedangkan informan 2, 5, dan informan 6 memanfaatkan akses jalan sekitar lingkungan sekolah sebagai tempat lintasan lari dalam pembelajaran atletik.

Hasil Pembelajaran lain yang di sampaikan oleh informan 1 guru Penjasorkes SMP Negeri 2 Ambal hampir membuat semua materi pembelajaran penjasorkes memanfaatkan lingkungan sebagai media pembelajaran. diantanya modifikasi bola kasti dengan menggunakan bola plastik kecil yang diisi dengan serbuk serabut kelapa dari sisa hasil pembuatan keset. Modifikasi media selanjutnya adalah memanfaatkan tutup ember cat yang dilubangi tengahnya untuk digunakan sebagai cone, atau wadah dari bola kasti. Media berikutnya yang dimanfaatkan adalah ember bekas yang dimanfaat sebagai bejana berlubang dalam pembelajaran atletik nomor lari.

Hasil temuan dilapangan dan teori dari beberapa ahli tentang pemanfaatan lingkungan sebagai media pembelajaran yaitu dengan cara modifikasi bola softball dengan sabut kelapa, kemudian menggunakan ember bekas untuk dijadikan bejana berlubang, memanfaatkan kertas yang tidak terpakai untuk dijadikan kertas tugas, dan memanfaatkan tutup ember cat untuk dijadikan cone. Selain itu, untuk membekali siswa akan sadar, paham dan perhatian serta tanggung jawab dengan lingkungan sekitar guru penjasorkes di daerah pesisir mengajak siswanya untuk melakukan pembelajaran di sekitar lingkungan sekolah seperti pantai, dan akses jalan sekitar sekolah

\section{KESIMPULAN}

Berdasarkan hasil penelitian dapat ditarik beberapa kesimpulan sebagai berikut:

1. Jenis lingkungan yang dimanfaatkan sebagai media pembelajaran atau sebagai tempat pembelajaran oleh guru penjasorkes SMP di daerah pesisir Kabupaten Kebumen adalah sebagai berikut, pertama tempat pembelajaran lingkungan yang dimanfaatkan berupa lapangan desa, pantai, dan jalan di sekitar lingkungan sekolah. Kemudian lingkungan yang dimanfaatkan sebagai media pembelajaran meliputi kertas tugas yang terbuat dari kertas undangan yang sudah tidak terpakai lagi dan bola berekor yang terbuat dari kertas bekas, kemudian bola plastik yang diisi dengan sabut kelapa, ember bekas dijadikan bejana berlubang, tutup ember cat dan papan kayu dijadikan sarana pembelajaran.

2. Cara yang dilakukan oleh guru penjasorkes SMP di daerah Pesisir Kabupaten Kebumen dalam memanfaatkan lingkungan sebagai media pembelajaran atau tempat belajar. Lapangan desa di daerah pesisir kabupaten kebumen dimanfaatkan untuk pembelajaran permaianan bola besar dan permainan bola kecil. Sedangkan pantai dan jalan disekitar lingkungan sekolah dimanfaatkan untuk pembelajaran atletik. Media pembelajaran yang memanfaatkan lingkungan di daerah pesisir meliputi, Kertas tugas yang terbuat dari sisa kertas bekas dan kertas undangan yang tidak terpakai, Kertas tugas ini berisi instruksi atau petunjuk untuk melakukan sebuah gerakan atau membuat sebuah gerakan atau permainan. Kemudia ada bola plastik kecil yang diisi dengan butir-butir sabut kelapa. Bola plastik kecil ini digunakan dalam permainan bola kecil yaitu permaian kasti dan modifikasi permainan softball. Sedangkan ember bekas cat yang dijadikan bejana berlubang. Ember atau bejana berlubang ini digunakan pada materi atletik yaitu nomor lari jarak pendek (sprint). Jadi bejana ini diisi air kemudian siswa berlari sambil membawa ember yang berisi air tersebut sampai garis finish.selain itu,tutup cat ember dan papan kayu digunakan sebagi 
sarana pendukung dalam proses pembelajaran.
Pembelajaran Pendidikan Jasmani, Olahraga, dan Kesehatan”. Bandung: Alfabeta

\section{DAFTAR PUSTAKA}

Adang Suherman. 2000. Dasar-Dasar Penjaskes. Jakarta: Depatemen Pendidikan Nasional Direktorat Jendral Pendidikan Dasar dan Menengah Bagian Proyek Penataan Guru SLTP dan Setara D- III.

Dini Rosdiani. 2013. Perencanaan Pembelajaran dalam Pendidikan Jasmani dan Kesehatan. Bandung: Alfabeta

Gulo, W. 2000. Metodologi Penelitian. Jakarta: Grasindo.

Herka Maya. J. 2005."Pemilihan Media Visual dalam Menunjang Pembelajaran Pendidikan Jasmani di Sekolah Dasar.Jurnal Pendidikan Jasmani Indonesia. Vol. 3. No. 1

Mia, Kusumawati. 2015. Penelitian Pendidikan Jasmani Olahraga dan Kesehatan. Bandung: Alfabeta

Nana Sudjana dan Ahmad Rifai. 2015. Media Pembelajaran.Bandung: Sinar Baru Algensindo.

Rahmat Kriyanto. 2009. Teknik Praktis Riset Komunikasi. Jakarta: Prenada Media

Risda Amini dan Mundandar, A. "Pengaruh Model Pembelajaran Pendidikan Lingkungan Berbasis Outdoor Terhadap Penguasaan Konsep Pendidikan Lingkungan Bagi Calon Guru Sekolah Dasar". Jurnal Penelitian Pendidikan Vol. 11, No. 1, April 2010: 412-565.

Setiawan Aji. P, Hermawan P.R, dan Harry Promono. 2012. Pengembangan Model Pembelajaran Kids Athletic Melalui Pendekatan Lingkungan Pantai. Journal Active. Vol. 1. No. 4. ISSN 225-6773.

Shoimin Aris. 2014. 68 Model Pembelajaran Inovatif dalam Kurikulum 2013. Yogyakarta: Ar Ruzz Media.

Tejo Nurseto. 2011. Membuat Media Pembelajaran yang Menarik. Jurnal Ekonomi dan Pendidikan. Vol. 8. Nomor 1

Trisna, R, E. 2013. Stratengi Pembelajaran Pendidikan Jasmani "Implementasi pada 